\title{
TEMUAN NASKAH-NASKAH KUNO DI MASJID LAYUR, SEMARANG, JAWA TENGAH
}

\section{ANCIENT MANUSCRIPTS FROM LAYUR MOSQUE, SEMARANG, JAWA TENGAH}

\author{
Masyhudi \\ Balai Arkeologi Yogyakarta
}

\begin{abstract}
The findings of ancient manuscripts in the ancient mosque on Layur Street, District of North Semarang known as Kampung Arab and lettered entirely in Arabic. Manuscripts were found on the roof of the mosque in a very poor condition, as most texts estimated to number in the tens of manuscripts have been destroyed, it cannot be identified. Through this paper the author will present a descriptive picture of the manuscript codex found in the Mosque Layur Semarang Central Java.
\end{abstract}

Keywords: Finding, Ancient Manuscript, Mosques Layur

\begin{abstract}
ABSTRAK
Temuan naskah-naskah kuno di dalam bangunan masjid kuno di Jalan Layur, Kecamatan Semarang Utara yang dikenal dengan nama Kampung Arab seluruhnya berhuruf dan berbahasa Arab. Naskah-naskah kuno tersebut ditemukan di bagian atap masjid dalam kondisi yang sangat memprihatinkan, karena sebagian besar naskah yang diperkirakan jumlahnya mencapai puluhan naskah telah hancur, sudah tidak bisa diidentifikasi. Melalui tulisan ini secara deskriptif penulis akan menyajikan gambaran tentang kondisi naskah naskah kuno yang ditemukan di Masjid Layur Semarang Jawa Tengah
\end{abstract}

Kata Kunci: Temuan, Naskah Kuno, Masjid Layur

\section{PENDAHULUAN}

Naskah (manuskrip) adalah semua jenis peninggalan tertulis pada bidang kertas, daluwang, kulit kayu, lontar, kulitr binatang dan lain sebagainya yang dapat memberikan sumbangan bagi kebudayaan di Indonesia. Pada umumnya naskah merupakan suatu dokumen yang mengandung pikiran, perasaan dan pengetahuan dari suatu kelompok masyarakat, sehingga dapat dijadikan sebagai sumber untuk penulisan sejarah dan arkeologi di Indonesia (Boechari, 1975).

Naskah kuno merupakan salah satu karya nenek moyang di masa lalu yang berfungsi sebagai bahan untuk membentuk dan memperkokoh jati diri bangsa, oleh karenanya naskah kuno perlu dilestarikan dan dimanfaatkan antara lain sebagai bahan untuk mengetahui atau memeroleh informasi mengenai nilai-nilai yang terkandung di dalam naskah. Untuk mengetahui isi dan makna suatu naskah, pertama-tama haruslah mengetahui tulisan yang digunakan dalam suatu naskah. Tulisan merupakan sarana untuk menyampaikan maksud, ide, dan gagasan suatu masyarakat.

Penelitian tentang naskah-naskah kuno pada umumnya untuk mengungkap kebudayaan dalam arti luas, maksudnya dengan naskah-naskah kuno yang dihasilkan 
dari suatu penelitian akan dapat terungkap persoalan-persoalan masyarakaat pada kurun waktu tertentu. Persoalan-persoalan tersebut meliputi tradisi, kepercayaan, pikiran maupun system nilai yang ada di masyarakat untuk menyesuaikan diri dengan situasi yang berkembang, baik dalam kehidupan masyarakat individual maupun dalam kehidupan masyarakat berkelompok (Robson, 1978).

Keberadaan data tekstual berupa naskah, pada kenyataannya di lapangan sangat sulit dilacak. Hal tersebut disebabkan oleh adanya sifat naskah yang moveable, yaitu mudah berpindah tangan dari pemilik asalnya. atau terkadang luput dari pengamatan peneliti, bahkan terkadang suatu naskah dirahasiakan keberadannya untuk dilihat atau diteliti oleh siapapun, karena benda tersebut telah dikeramatkan. (Ekadjati, 1983).

Pengetahuan yang berhubungan dengan studi naskah atau studi yang dilatarbelakangi oleh suatu naskah kuno disebut filologi. Maksudnya studi tersebut untuk berupaya mengungkap hasil budaya suatu bangsa melalui kajian naskah atau sumber tertulis. Hal demikian sering dilakukan dalam suatu penelitian, akan tetapi secara teknis belum menampakkan suatu sistematika yang runtut yang sering muncul pada saat akan melakukan analisis.

Naskah-naskah kuno di kampung Arab merupakan bukti keberadaan etnis Arab di beberapa kota di Jawa. Bukti-bukti lain di antaranya adalah masjid, makam, rumah tinggal. Naskah kuno merupakan budaya materi yang memiliki sifat mudah berpindah atau mudah bergerak. Kondisi semacam ini akan membuat benda benda tersebut akan cepat hilang atau berpindah tangan. Dari beberapa kampung Arab yang terdapat di beberapa kota di Jawa Tengah hanya kampung Arab di Semarang yang masih terdapat peninggalan naskah-naskah kuno. Ironisnya naskah naskah telah mengalami kerusakan sebagai akibat penyimpanan yang tidak bagus dan tidak banyak diketahui orang dan bahkan telah banyak naskah yang rusak akibat lapuk termakan ngengat. Persoalannya adalah bagimana sebaiknya menyikapi naskah-naskah kuno yang kini dalam kondisi tidak terawatt tersebut

Tujuan penulisan ini adalah untuk mengungkap keberadaan naskah-naskah kuno yang ditemukan di tengah-tengah masyarakat etnis Arab di Semarang, dan secara deskriptif kualitatif akan menyajikan gambaran tentang matan naskah naskah kuno yang ditemukan di Kampung Arab Semarang Jawa Tengah.

\section{NASKAH-NASKAH KUNO PADA MASA AWAL ISLAM DI JAWA SEKITAR ABAD KE- 15/16 MASEHI}

Naskah-naskah kuno dapat dipandang sebagai suatu tradisi besar (Great Tradition) Islam di Indonesia, yang memuat perekaman tradisi keilmuan agama Islam dalam bentuk karya tulis. Secara umum naskah naskah tersebut berisi tentang keilmuan agama Islam yang berkaitan dengan tafsir, hadits, usul al-figh, akidah/ ushuluddin, tasawuf dan tarekat, tata bahasa Arab tradisionil (nahu, sharaf, balaghah), akhlak, kumpulan do'awirid, mujarabad, qishash Al-Ambiya, maulid, manaqib, dan sebagainya (Bruinessen, 1999: 134-135).

Para ulama penulis naskah sudah barang tentu menduduki peran penting sebagai agen pelaku tradisi keilmuan agama Islam sepanjang perjalanan proses Islamisasi di Indonesia. Untuk mengidentifikasi dan memahami hadirnya pernaskahan di Jawa, paling tidak dapat dirunut melalui beberapa periode penting, antara lain pada masa awal kelahiran pusat kerajaan Islam di Pesisir utara Jawa (Demak, Cirebon, Banten) pada abad ke 16; pada masa kerajaan Islam Mataram pada abad 17-18; masa pemerintahan kolonial Belanda pada abad ke-19/ awal abad ke20; dan pada masa kemerdekaan. Periodisasi ini didasarkan pada pertimbangan adanya hubungan antara kelahiran kelembagaan Pesantren dengan pusat-pusat sejarah (histrorical centers) politik (pusat kerajaan Islam, pemerintahan penjajahan, dan pemerintahan pasca penjajahan) pada zamannya. Mengingat adanya hubungan interaktif antara keduanya, maka keberadaan pernaskahan yang memuat tradisi keilmuan agama Islam sesungguhnya bisa ditemukan selain di dunia pesantren, juga di dalam dunia istana kerajaan Islam, Arsip Pemerintahan 
Kolonial Belanda, Arsip Nasional, Perpustakaan Nasional Indonesia, dan lembaga yang sejenis.

Pada masa awal berdirinya pemerintahan kerajaan Islam yang berpusat di Pesisir Utara Jawa, yaitu di Demak, Cirebon, dan Banten yang dikenal sebagai periode kelahiran raja Islam yang bergelar Sultan sebagai penguasa politik negara Islam (Umara') bersama dengan Ulama, yaitu yang dikenal sebagai para Wali, bertanggungjawab dalam penyebarluasan agama Islam di Jawa. Pusat-pusat pengajaran Islam selain di pusat istana, tersebar di pusat kediaman para Wali, seperti Gresik, Giri, Tuban, Murya, Kudus, dan lainnya. Pada pusat-pusat perguruan tersebut transmisi ajaran Islam berlangsung. Penulisan dan penyebaran naskah kitab-kitab keilmuan mulai berkembang melalui para Wali sebagai mubalig utamanya. Sekaligus para penulis naskah kitab kuning, yaitu para Ulama sebagai pemimpin perguran Islam dapat dipandang sbagai cikal bakal "Pesanten". Naskah-naskah "Pesantren" awal ini pada masa kemudian sangat berharga sebagai warisan budaya intelektual dunia Pesantren Pesisir Utara Jawa.

Beberapa naskah keilmuan agama Islam yang penting yang lahir pada masa itu di antaranya ialah, naskah 'Naskah Wejangan Sheh Bari' ( Drewes, 1969); "Kitab Sunan Bonang" (Schrieke, 1916); Een Javaanse Primbon uit de zestiende eeuw (De Goeje Foundation, 1954); dan berbagai naskah lain termasuk karya-karya Suluk (tasawuf, mistik Islam), serta karya-karya Sastra Religius Pesisiran.

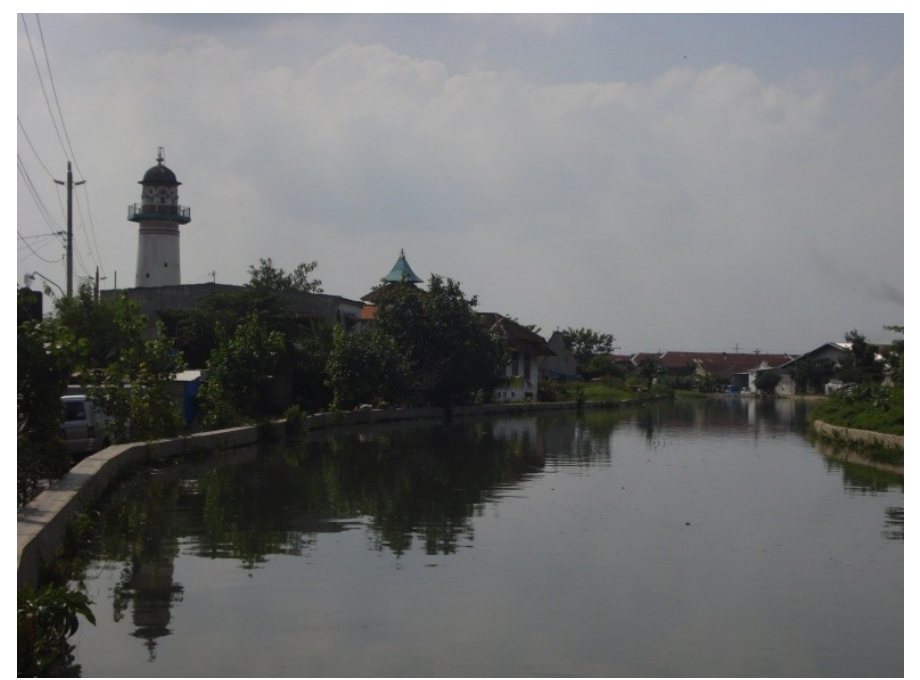

Foto 1. Masjid Layur di Kampung Arab Semarang, tempat ditemukannya naskah-naskah kuno

\section{NASKAH KUNO DI MASJID LAYUR KOTA SEMARANG}

\section{Keberadaan Naskah-Naskah Kuno}

Masjid Layur, atau yang disebut pula Masjid Menara merupakan masjid kuno yang mempunyai ciri khas, yaitu nampak pada bangunan menara yang berbentuk silindris yang dilengkapi dengan hiasan geometris dan pada bagian tengah dan atas terdapat bidang datar berbentuk segi delapan serta terdapat kubah pada bagian atasnya. Namun demikian pengaruh Arab ini tidak nampak lagi ketika orang memasuki halaman. Bangunan masjid sendiri tidak bergaya Arab, tetapi memiliki lebih banyak unsur lokal. Lantai bangunan dinaikkan dan hanya dapat dicapai dengan tangga yang terdapat pada sisi muka. Kolong masjid dulu pernah berfungsi sebagai tempat untuk mengambil air wudhu, tetapi kini sudah tidak bisa lagi dimanfaatkan karena kondisi sekarang yang sudah terendam oleh naiknya permukaan air laut, bahkan sejak sekitar sepuluh tahun yang lalu telah terendam air rob. Kalau atap kubah menara terdiri dari sirap, lain halnya dengan atap masjid yang berbentuk tajuk bersusun tiga dan tertutup genteng. Bisa jadi 
dulu penutup atapnya juga dari sirap tetapi pada masa tertentu diganti dengan genteng dengan alasan perawatan.

Keberadaan Bangunan masjid Menara telah diperkuat dengan ditemukannya sejumlah naskah kuno. Naskah-naskah ditemukan di atap masjid, berkat informasi pengurus masjid yang lama yang juga beretnis Arab, yaitu Habib Muhsin yang pada saat tulisan ini di buat beliau tinggal di tempat yang relatif jauh dari lokasi masjid Layur. Di antara naskah naskah tersebut ada yang mengindikasikan bahwa masjid tersebut dibangun oleh orang-orang Arab di Semarang. Akan tetapi secara kronologis, kapan masjid tersebut didirikan ? tidak ada informasi angka tahun, baik melalui narasumber dari naskah-naskah kuna maupun dari bangunan masjid Layur tersebut. Salah satu teks naskah yang mengindikasikan bahwa naskah tersebut merupakan haknya masjid yang dibangun oleh masyarakat etnis Arab adalah naskah tentang Khutbah Idul-Fitri. Secara lengkap teks naskah bertuliskan:

$$
\text { خطبة عيد الفطرحق مسجد العرب في سما ران }
$$

\section{Transliterasi}

Khuthbatu 'idil-fithri haqqu

Masjidil 'Arabi fi Samarani

Artinya khuthbah 'idul-fithri adalah haknya masjid orang-orang Arab di Semarang. Atau dapat diinterpretasikan bahwa kitab khuthbah 'idul-fitri adalah haknya masjid orang-orang Arab di Semarang (Masyhudi :2009).

Naskah-naskah kuno di Kampung Arab

Kota Semarang berjumlah 9 (sembilan) eksemplar dan seluruhnya terbuat dari bahan

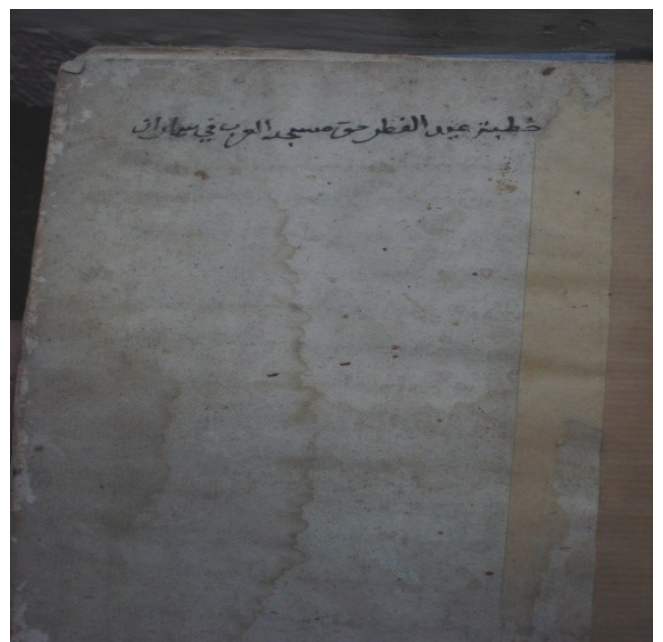

Foto 2. Naskah berhuruf dan berbahasa Arab Berisi tentang khutbah idul-Fitri

kertas Eropa. Berdasarkan kandungan atau muatan yang terdapat di dalam naskah, termasuk pada jenis naskah agama yang terbagi dalam beberapa jenis, yaitu Fikih 2 eksemplar, aqidah dan tauhid 2 eksemplar, Dziba' dan barzanji 2 eksemplar, kitab khuthbah 2 eksemplar (idul-fitri dan idul-adha) dan satu eksemplar kitab Mi'raj Nabi Muhammad saw. Naskah naskah tersebut seluruhnya di tulis dengan menggunakan huruf dan bahasa Arab, sedangkan gaya tulisan pada naskah, mengunakan gaya naskhi dan Tsuluts, tetapi lebih dominan gaya naskhi dari pada gaya tsuluts .

Mengenai kronologi, hampir tidak ada data yang menunjukkan angka tahun tentang kedatangan bangsa Arab di Kota Semarang. Namun demikian dari data yang ada memberikan gambaran bahwa masyarakat etnis Arab di Semarang tidak akan terlepas dari kebiasaan hidup mereka, yaitu berlayar dan berdagang. Mereka hidup di Kampung Melayu, sementara itu, Kampung Melayu sudah ada sejak pertengahan abad XVIII Masehi (tahun 1743). Akan tetapi karena Kampung Melayu merupakan suatu lokasi yang sangat strategis dan terdapat tempat untuk mendarat kapal-kapal dan perahu yang membawa barang dagangan, maka hal itu akan mengundang orang untuk ingin tinggal di tempat tersebut., Diduga dalam waktu yang tidak lama orang-orang Arab kemudian menempati kampung tersebut dan pada masa itulah kiranya masyarakat etnis Arab mulai membangun masjid serta melakukan berbagai aktivitas keagamaannya.

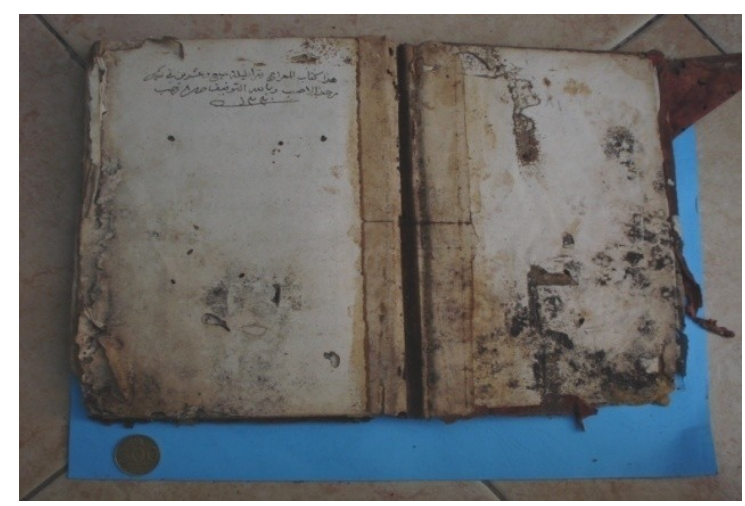

Foto 3. Naskah kuno berkolofon ditemukan di bagian atap Masjid Layur 
Dengan demikian diduga kuat bahwa keberadaan masyarakat etnis Arab di Kampung Melayu Semarang Utara sudah ada sejak abad XIX Masehi. Hal tersebut diperkuat dengan ditemukannya naskah-naskah kuno yang menjelaskan bahwa masjid Menara yang berada di Jalan Layur Semarang Utara adalah masjidnya orang-orang Arab. Ada kemungkinan naskah-naskah tersebut ditulis pada masa kemudian, tetapi juga tidak menutup kemunggkinan naskah-naskah yang lain mereka bawa dari negeri asalnya.

Secara fisik sebagian besar naskah telah hancur, akan tetapi dari naskah yang tersisa dapat dilakukan pengamatan melalui watermark yang biasanya terdapat pada lembaran lembaran kertas buata Eropa. Dari hasil pengamatan yang dilakukan memalui watermark yang ada tampak pada naskah adanya gambar Singa bermahkota berada di dalam dua buah lingkaran dengan tulisan CONCORDIA. Naskah tersebut kebanyakan berkembang di Indonesia pada sekitar abad XIX Masehi.

Pada bagian naskah yang lain terdapat kolofon, yaitu suatu tanda yang digunakan menjelaskan suatu nama kitab dan waktu selesainya penulisan suatu kitab. Kolofon yang terdapat pada naskah adalah

Ini adalah kitab tentang Mi'raj yang dibaca pada malam 27 bulan Rajab dan pada bagian bawah terdapat angka tahun Hijriyah ; 1220.

Berdasarkan data tersebut dapat diperkirakan bahwa naskah dengan watermark menunjuk pada abad XIX Masehi, bersamaan dengan masa-masa ramainya perdagangan di Kampung Melayu. Adapun angka tahun pada kolofon naskah $1220 \mathrm{H}$, bila dikomversikan dengan angka tahun masehi akan jatuh pada tahun 1840-an Masehi (pertengahan abad XIX). Akan tetapi besar kemungkinan naskah tersebut diajarkan oleh masyarakat etnis Arab setelah mereka benar benar telah menetap di kampung tersebut, sehingga dapat diduga dengan kuat bahwa masyarakat etnis Arab telah menunjukkan eksistensinya di Semarang Jawa Tengah sejak abad XIX Masehi.

\section{Penanganan Terhadap Naskah Naskah Kuna}

Derasnya arus dan kayanya ragam informasi yang diterima oleh masyarakat Indonesia tampaknya belum mampu menciptakan kesadaran yang utuh dalam memiliki kepedulian yang tinggi terhadap peninggalan-peninggalan budaya dan sejarah Nusantara yang dimiliki bangsa kita. Oleh karena itu perlu adanya sosialisasi secara terus-menerus kepada masyarakat luas, agar masyarakat mau mengapresiasinya. Apersiasi dapat dilakukan dengan jalan mengenal, memahami, dan mempelajarinya, sehingga dari sana diharapkan timbul kepekaan serta kepedulian untuk memeliharanya.

Adanya suatu fenomena, yaitu tidak banyaknya kalangan masyarakat yang antusias dan peduli pada hal-hal semacam ini adalah disebabkan karena benda benda tersebut dianggap tidak menguntungkan (bernilai ekonomis) bagi kelangsungan hidup manusia. Anggapan ini tentu saja keliru karena warisan budaya merupakan satu aset besar yang dimiliki bangsa ini dengan berbagai potensinya yang sebagian besar masih belum terkuak. Hanya saja, tergantung pada bagaimana kita menempatkannya dalam kerangka berpikir positif, sehingga warisan budaya tersebut dapat dikemas sedemikian rupa demi mendatangkan keuntungan, jika itu yang dicari atau mendatangkan kemaslahatan bagi masyarakat pemiliknya. Ditemukannya naskah-naskah kuna di bagian atap masjid Layur Semarang, adalah menjadi bukti kurang adanya kepedulian masyarakat terhadap peninggalan-peninggalan tertulis.

Naskah kuna adalah bukti sejarah yang memiliki nilai penting bagi pendidikan dan kebudayaan di Indonesia. Akan tetapi hingga sekarang data tekstual tersebut tidak begitu banyak muncul sebagai data yang akurat. Hal ini dikarenakan semakin berkurangnya data tekstual yang mampu mengungkap peristiwa peristiwa di masa lampau bahkan juga disebabkan oleh sifat benda itu sendiri uang mudah bergerak dan berpindah tangan (moveable). 


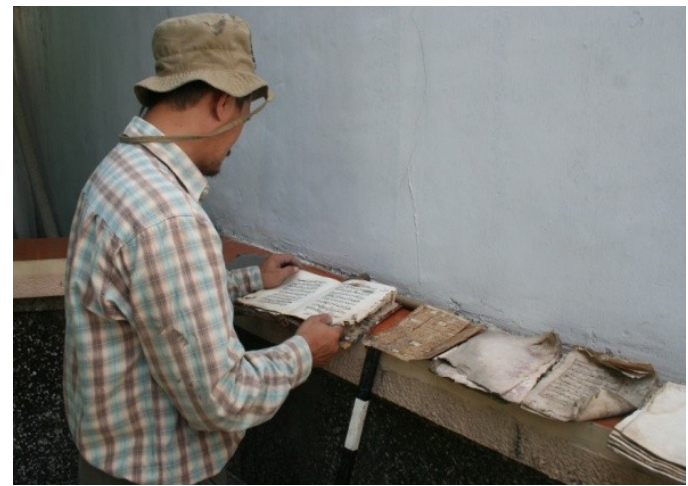

Foto 4. Penaganan naskah-naskah kuno yang ditemukan di masjid Layur Semarang Jawa Tengah

Demikian halnya naskah-naskah kuna yang berangka tahun, sampai sekarang masih jarang ditemukan. Sehingga untuk mengungkap kronologi suatu naskah hanya dapat diperkiran melalui teknologi pembuatan naskah dan watermark yang terdapat di dalam naskah.

Secara fisik sebagian besar naskah yang ditemukan di Masjid Layur Semarang telah hancur, namun demikian dari naskah yang tersisa dapat dilakukan pengamatan melalui watermark yang biasanya terdapat pada lembaran lembaran kertas buatan Eropa. Dari hasil pengamatan yang dilakukan memalui watermark yang ada tampak pada naskah adanya gambar Singa bermahkota berada di dalam dua buah lingkaran dengan tulisan CONCORDIA. Naskah-naskah kuno dengan watermark sebagaimana tersebut di atas kebanyakan berkembang di Indonesia pada sekitar abad XVIII-XIX Masehi. Pada bagian naskah yang lain terdapat kolofon, yaitu suatu tanda yang digunakan menjelaskan suatu nama kitab dan waktu selesainya penulisan suatu kitab.

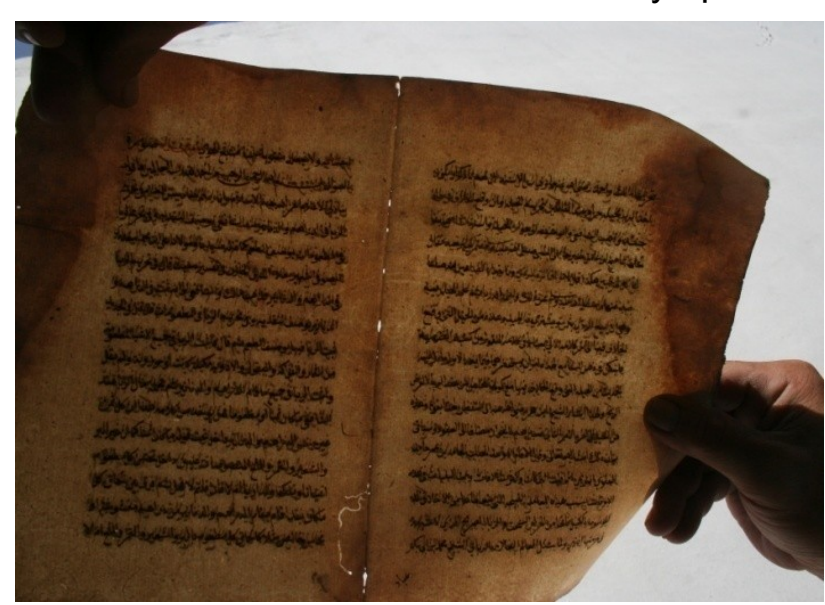

Foto 5. Temuan Naskah kuno berhuruf dan berbahasa Arab di Masjid Layur Semarang

Kolofon yang terdapat pada naskah adalah:

Ini adalah kitab tentang Mi'raj yang dibaca pada malam 27 bulan Rajab

Dan pada bagian bawah terdapat angka tahun Hijriyah ; 1220.

Berdasarkan data tersebut dapat diperkirakan bahwa naskah dengan watermark menunjuk pada abad XIX masehi identik dengan masa-masa ramainya perdagangan di Kampung Melayu. Adapun angka tahun pada kolofon naskah $1220 \mathrm{H}$, bila dikomversikan dengan angka tahun

Masehi akan jatuh pada kisaran tahun 1840-an Masehi (pertengahan abad XIX). Akan tetapi besar kemungkinan naskah tersebut diajarkan oleh masyarakat etnis Arab setelah mereka benar benar telah menetap di kampung tersebut.

Serangkaian uraian di atas, setidaknya mampu memberikan pemahaman awal kepada kita tentang pentingnya upaya-upaya pelestarian tinggalan budaya di tengah derasnya arus globalisasi. Penggalian, pendokumentasian dan perawatan, pelestarian, hingga pada akhirnya penyajian kepada dunia adalah langkah yang harus ditempuh demi lestarinya budaya yang kita miliki.

Naskan kuno adalah bukti sejarah yang memiliki nilai penting bagi pendidikan dan kebudayaan di Indonesia, akan tetapi data tersebut hingga kini tidak banyak muncul sebagai bukti yang akurat. Hal ini disebabkan oleh sifat benda yang moveable (mudah bergerak), sehingga semakin berkurangnya data tekstual yang mampu mengungkap peristiwa-peristiwa di masa lampau.

Kekuatan budaya merupakan tujuan akhir dari pembangunan dan jati diri bangsa, karena identitas dan karakter dari suatu bangsa dipengaruhi oleh budayanya, baik lokal maupun nasional. Hal ini dikarenakan kekuatan budaya merupakan suatu sistem pertahanan paling vital bagi suatu bangsa dan negara. Oleh karenanya, Jika naskahnaskah kuno sebagaimana terdapat di kampung Arab Kota Semarang tidak ditangani 
secara baik, jati diri bangsa akan bergeser dari akar budaya bangsa. Semoga hal ini bisa menjadi bahan renungan kita bersama.

\section{PENUTUP}

Dari uraian tersebut di atas dapat disimpulkan bahwa, naskah-naskah kuno tulisan tangan merupakan warisan budaya yang mengandung teks tertulis mengenai berbagai pemikiran, pengetahuan, adat istiadat serta prilaku masyarakat pendukungnya pada masa silam. Benda yang menjadi cagar budaya ini masih bertebaran di tengah masyarakat.

Naskah-naskah kuno yang menjadi salah satu sumber yang dapat memberikan informasi tentang perkembangan teknologi, dan sejarah masa lalu itu sejauh ini keberadaannya masih terbengkalai, sebagaimana halnya naskah-naskah kuno yang ditemukan di bagian atap Masjid Layur. Padahal naskah tersebut mengindikasikan bahwa Masjid Menara yang berada di Jalan Layur Semarang Utara adalah masjidnya orang-orang Arab. Secara fisik sebagian besar naskah telah hancur, akan tetapi dari naskah yang tersisa dapat dilakukan pengamatan melalui watermark yang biasanya terdapat pada lembaran lembaran kertas buata Eropa.

Kurangnya antusias masyarakat pada benda-benda warisan budaya adalah disebabkan karena benda benda tersebut dianggap tidak menguntungkan (bernilai ekonomis). Bahkan sampai saat ini penelitian terhadap naskah-naskah kuno lebih mementingkan telaah teks, Persoalan yang berkaitan dengan pengkoleksian dan pemeliharaan naskah diabaikan. Padahal, sumber naskah hanya dapat diacu apabila sumber itu telah dilestarikan. Dengan kata lain penelitian tentang naskah-naskah baru dapat dilakukan apabila kondisi naskah baik fisik maupun tulisan tidak mengalami kerusakan. Oleh karena itu, naskah-naskah yang masih tersebar di kalangan masyarakat perlu diselamatkan dengan cara mengumpulkannya pada suatu tempat atau lembaga resmi negara. Bagaimanapun juga naskah-naskah kuno merupakan kekayaan budaya bangsa yang sangat penting artinya bagi pemahaman dan pengembangan sejarah, ilmu pengetahuan, serta kebudayaan sehingga perlu dilestarikan untuk pemupukan jati diri bangsa

\section{KEPUSTAKAAN}

Boechari, 1975, Manfaat Studi Bahasa Jawa Kuno Ditinjau Dari Sejarah dan Arkeologi, Majalah Arkeologi I, Jakarta.

Bruinessen, Martin van. 1999.Kitab Kuning. Pesantren dan Tarekat. Tradisi Islam di Indonesia. Bandung:Penerbit Mizan, Terbitan ke III.

De Goeje Foundation. Een Javaanse Primbon uit de zestiende eeuw (Leiden: E.J. Brill, 1954.

Drewes, G.W.J. The Admonitions of She Bari. A $16^{\text {th }}$ century Javanese Muslim text attributed to the Saint of Bonang. The Hague: Martinus Nijhoff, 1960.

Ekadjati, Edi S, 1983, Naskah Sunda, Inventarisasi dan Pencatatan Lembaga Kebudayaan Universitas Padjadjaran, Toyota Foundation, Bandung.

Ricklefs, M.C. 2006. Mystic Syntheses in Java. History of Islamization from the Fourteenth to the Early Nineteenh Centuries. Norwalk: EasBridge. 
1998, The Seen and Unsee Worlds in Java. History, Literature and Islam in Court of Paku Buwwana II. Honolulu: Allen \& Unwin, Universiy of Hawaii.

Masyhudi. 2009. Keberadaan Perkampungan Arab di Semarang dan Surakarta, Balai Arkeologi Yogyakarta.

Robson Stuart, Pengkajian Sastera-Sastera Indonesia, Dalam Bahasa dan Sastera, IV Jakarta.

Schrieke, 1916, B.J.O. Het Boek van Bonang. Disertasi. Leiden. 